\title{
ASSESSMENT OF THE NUTRITIONAL POTENTIAL OF THE KERNELS OF THE SEEDS OF TETRACARPIDIUM CONOPHORUM COLLECTED IN LÉKANA IN THE DEPARTMENT OF PLATEAUX IN THE REPUBLIC OF CONGO
}

\author{
Ossoko Jean Paul Latran1,2; Dzondo Gadet Michel2,3; B.D.E. Miakayizila Blaise Divin Emmanuel1,2,3; Mvoula \\ Tsieri Michel Didace ${ }^{1,4}$ \\ 'Laboratoire de Contrôle Qualité des Aliments. ENSAF : Ecole Nationale Supérieure d'Agronomie et Foresterie (Université Marien \\ NGOUABI) Brazzaville CONGO. \\ 2Institut National de Recherche en Sciences de l'Ingénieur, Innovation et Technologie (Ministère de la Recherche Scientifique et de \\ I'Innovation Technologique, CONGO-Brazzaville). \\ ${ }^{3}$ Ecole Nationale Supérieure Polytechnique, Université Marien NGOUABI, Brazzaville \\ ${ }^{4}$ Université Denis SASSOU NGUESSO, Brazzaville
}

Tetracarpidium conophorum, commonly known by the names, African nut, kaso or
"Nkah" in Congo, belongs to the Euphorbiaceae family. It is a rainforest plant that can
also be found in shrubs in the Republic of Congo, in the wild. Its seeds contain almonds
rich in fat (47.15\%), protein (33.95\%), with a moisture content of $4 \%$. The carbohydrate
content is relatively low (7.77\%). The fibers and the ashes represent respectively: $0.15 \%$
and $9.14 \%$. Among the minerals identified are: Phosphorus: $1.46 \%$, Iron: $0.01 \%$, Calcium:
$1.57 \%$, Magnesium: $0.19 \%$ and Nitrogen: $5.45 \%$. The calculated energy value is 591.23
Kcal / 1009 .

Keywords: Tetracarpidium conophorum, Seeds, Almonds, Characterization. 


\section{INTRODUCTION}

Congo is one of the countries that constitute the green lung of the world. It is rich in very diverse flora and fauna. The Congolese vegetation has several types of species recorded to date. Unfortunately, this capital is insufficiently exploited and makes the country dependent on food imports to meet the needs of its population. This dependence is particularly observed in the areas of fats and proteins. In recent years, there has been a resurgence of interest in unconventional crops with potential assets for both the development of populations at the local level and that of industry [1].

The promotion of local plants as sources of lipids, proteins or carbohydrates sometimes leads us to rare specimens that can be the subject of in-depth study. Tetracarpidium conophorum which is the subject of our study is one of the plants that grow in the wild in Congo-Brazzaville and has never been the subject of usual culinary applications (industrial production of oil for example), but very often used for aphrodisiac purposes.

Tetracarpidium conophorum, commonly called "Nkah" in the Téké language of Congo (in the study area), belongs to the Euphorbiaceae family. It is present in rainforests, in most shrubs, mainly in the region of the plateaux, the West Cuvette and the Cuvette. The fruit it produces is a capsule 7 to $9 \mathrm{~cm}$ wide, 3 to $3.5 \mathrm{~cm}$ high; provided with tough radial wings, having four star compartments (sometimes three per abortion); inside each lobe is a large sub-globose seed with a black, thin, sclerified, very hard seed coat, whitish endosperm with thin leafy cotyledons.

In the Congo, Tetracarpidium conophorum has not yet been thoroughly studied because it grows in the wild and has never been the subject of attempted domestication. However, it is likely that the plant is useful from a nutritional and cosmetic point of view, but also economically in the country. Almonds in particular can be a great asset if we can determine their physicochemical and biochemical characteristics.

This present work will therefore constitute a contribution to the knowledge of the real nutritional potential of the almonds of Tetracarpidium conophorum in order to consider their valuation in the areas where this plant grows.

\section{MATERIAL AND METHODS}

\section{II.1. Plant material}

The plant material of our study consists of almonds extracted from the seeds of the pods of Tetracarpidium conophorum, collected in Lekana, in the Plateaux Department in the Republic of Congo.

Figures (II.1; II.2; II.3) below show, respectively, whole seeds, fresh almonds, dried and then ground almonds of Tetracarpidium conophorum 


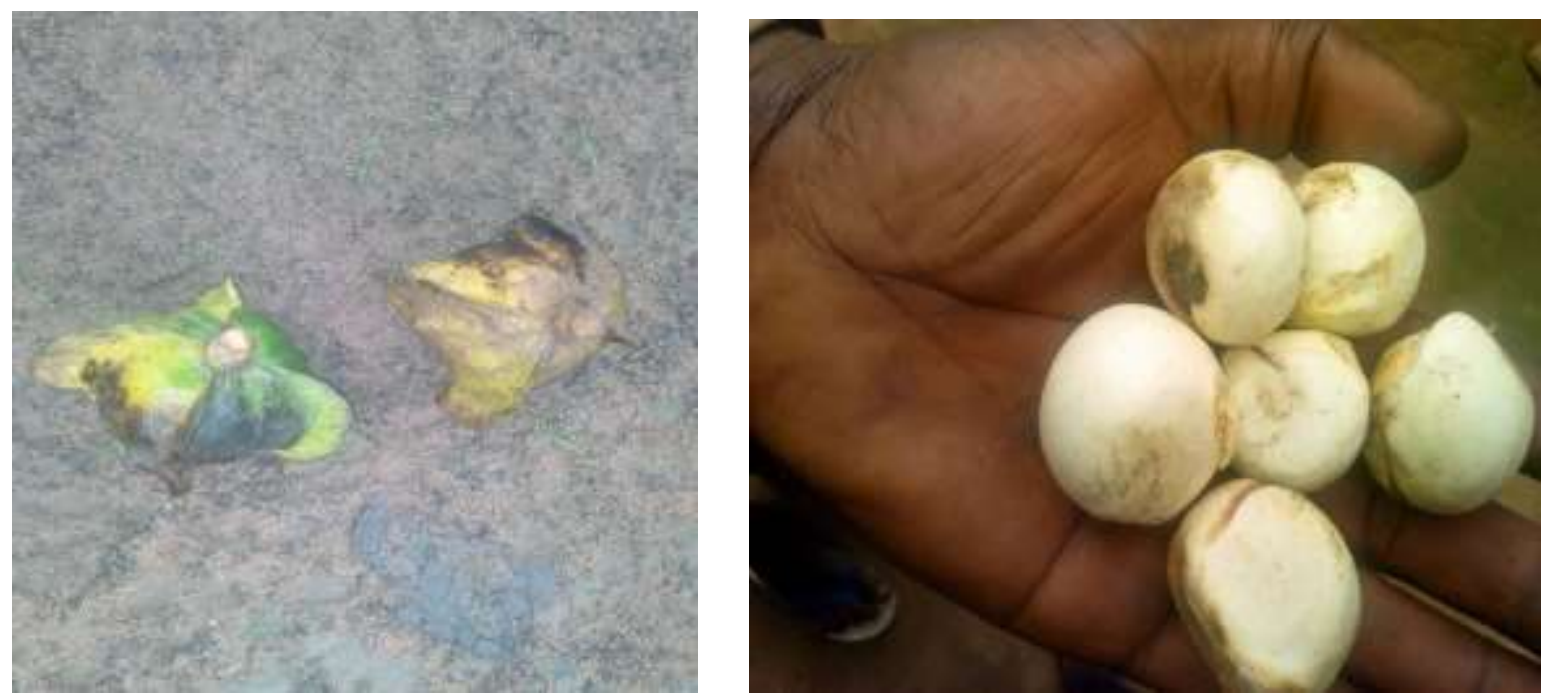

Figure II.1: Whole seeds of T. conophorum Figure II.2: Fresh almonds of $T$. conophorum

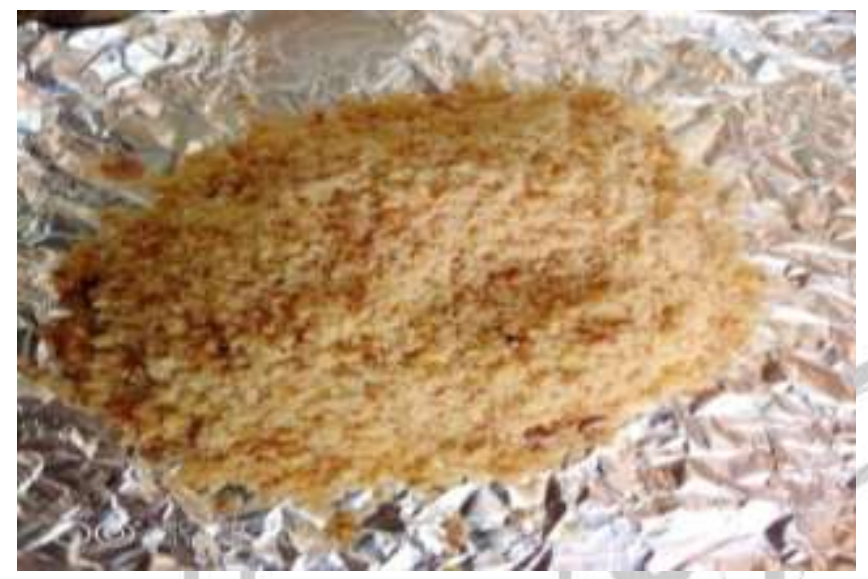

Figure II.3: Ground dried almonds of Tetracarpidium conophorum

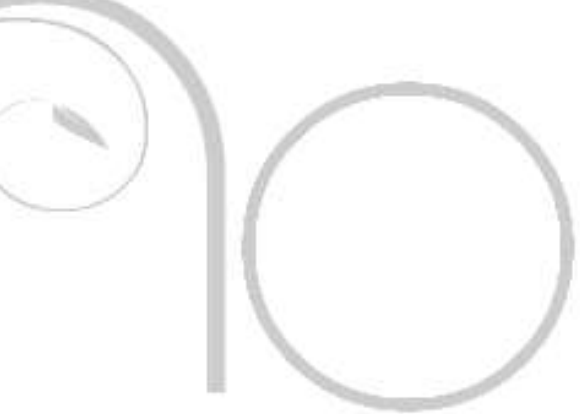

\section{II.2. Methods}

The methods used in this study are described below:

\section{Determination of humidity level $(\mathrm{H})$ [2]}

The moisture content was determined as follows: $2 \mathrm{~g}$ of ground almonds extracted from the ripe fruit are placed in a capsule weighed beforehand and placed in an oven (Memmert, Germany) at $70^{\circ} \mathrm{C}$ until the mass becomes constant.

\section{Determination of lipid level (MG)}

The lipids contained in $5 \mathrm{~g}$ of dried and crushed almonds were extracted according to the Soxhlet method (NF ISO $8262-3,2006$ ) in $200 \mathrm{~mL}$ of hexane for 6 hours. The excess solvent is evaporated off in a rotary evaporator (IKA HB 10 basic).

\section{Determination of protein level (P) [2]}

About $0.1 \mathrm{~g}$ of ground almonds are used to determine the level of crude protein from the determination of total nitrogen by the Kjeldhal method. The protein content was obtained by multiplying the total nitrogen content by a convention factor of 6.25.

Determination of crude ash and mineral content ( $C$ and $M$ ) [2]

$2 \mathrm{~g}$ of deoiled ground almond cake were used to determine the ash content using the gravimetric method. The samples were incinerated in a muffle furnace at $550^{\circ} \mathrm{C}$ for 6 hours. The ash content obtained after incineration is then calculated. 
Phosphorus, calcium, sodium, potassium, magnesium and iron were measured by cold colorimetric method, atomic absorption spectrometry (AAS) and flame emission spectrometry.

\section{Determination of the total carbohydrate content (G) [2]}

The carbohydrate content (G) was estimated by the difference method. According to the method, it was calculated by subtracting from 100 the sum of moisture (H), fat (MG), protein (P) and ash (C) contained in the sample.

\section{Determination of the fiber content ( $F$ ) [3]}

The raw fiber contents of the samples were determined by the Weende method: $1 \mathrm{~g}$ of grated almonds (M) was brought to the boil in $50 \mathrm{ml}$ of sulfuric acid
$(0.25 \mathrm{~N})$ and then in $50 \mathrm{ml}$ of soda $(0.31 \mathrm{~N})$ for 1 hour. The obtained residue was dried at $105^{\circ} \mathrm{C}$ for 8 hours and then incinerated at $550^{\circ} \mathrm{C}$ for 3 hours.

\section{Determination of the Energy Value (EV)}

The total energy value was calculated according to the method of Manzi (1999) cited by Diallo Koffi et al. [4].

It is determined using the following formula:

VE $(\mathrm{kcal} / 100 \mathrm{~g})=(\mathrm{CHO} \times 4)+(\mathrm{CL} \times 9)+$ $(\mathrm{CP} \times 4)$ with $\mathrm{CHO}=\%$ of carbohydrates, $C L=\%$ of fat and $C P=\%$ of protein.

\section{Results and discussion}

\section{III.1 Results}

The table below represents the biochemical composition of the dry almonds of Tetracarpidium conophorum

Table 1: Average physicochemical composition of Tetracarpidium conophorum almonds

\begin{tabular}{ll}
\hline Water content & $\mathbf{4 \%}$ \\
\hline Lipid content & $47.15 \%$ \\
\hline Protein content & $33.95 \%$ \\
Ash content & $9.14 \%$ \\
\hline Carbohydrate content & $7.77 \%$ \\
Dietary fiber content & $0.15 \%$ \\
\hline Energetic value & $591.23 \mathrm{Kcal} / 100 \mathrm{~g}$. \\
\hline
\end{tabular}

Analysis of the ash identified the following mineral elements: phosphorus, iron, calcium, magnesium and nitrogen. We thus obtained: Phosphorus: $1.46 \%$, Iron: 0.01\%, Calcium: $1.57 \%$, Magnesium: $0.19 \%$, and Nitrogen: $5.45 \%$.

\section{III.2 Discussion}

\section{Water content}

The various tests carried out to obtain the water content gave an average value of $4 \%$ on the kernels of Tetracarpidium conophorum studied. This value is low compared to those obtained by certain authors (Nwaguikpe et al., in 2012) [5] who obtained a value of $39.27 \%$; Onawuni et al., in 2013 [6]) obtained a value of 29\%; Sura et al., in 2016 [7]) obtained a value of $6.86 \%$ and Chikezie and Uchechukwu in 2017 [8] obtained a value of $5.46 \%$, working on the same product.

The relatively low value for water content could be justified by the fact that the seeds were stored for about three months at room temperature before being analyzed. The value obtained is also very low compared to the average values obtained by Liu et al., in 2008 [9], Malacrida and Jorge in 2012 [10], all working on the seeds of Passiflora edulis $f$. flavicarpa Degener, the values of which are respectively $10.8 \%$ and $7.38 \%$. This difference would probably be due to the condition of the fruits or to the growing area of the latter. This rate $(4 \%)$ is also found to be very low compared to that of 
Cocos nucifera $94.45 \%$, obtained by Jean et al., in 2009 [11]; it is also less than $56.33 \%$, a value obtained by Kabiru et al. in 2015 [12] on fresh almonds from Borassus aethiopum; which allows us to conclude that the fresh seeds of the studied fruit are less hydrated than the fresh almonds of Borassus aethiopum and therefore keep better than the latter.

This rate of $4 \%$ is also low compared to those obtained by various authors on other products such as peanuts with: 7.48\%, value obtained by Ayoola and Adeyeye in 2010 [13]; Ayoola et al. in 2012 [14] on peanut seeds lraw groundnut, sun-dried groundnut and roasted groundnut); 5.55-6.05\% (Brintha et al., in 2014 [15], on a peanut variety in Sri Lanka after treatments with organic fertilizers; $7.18 \%$ obtained by Adegoke Bosede et al. in 2014 [16 ], on a variety of peanuts from Nigeria.

It can be noted that this water content of $4 \%$ is normal for good preservation of the seeds. The moisture content of the seeds varies between 10 and $14 \%$. So for better conservation, the seeds must be lightly dried beforehand after their harvest.

\section{Lipid content}

Soxhlet extraction of Tetracarpidium conophorum almonds gives an average lipid content of around $47.15 \%$. This value is very high compared to certain values found by other authors on the same product: $5.19 \%$, value obtained by Nwaguikpe et al. in 2012 [5]; 5.63\%, value obtained by Onawuni and Ayoola in 2013 [6], on boiled almonds and $21.61 \%$, value found by Suara et al., In 2016 [7]. Chikezie in 2017 [8] obtained a higher value of $53.74 \%$ compared to $47.15 \%$ (value obtained in this study) on the same product. This value obtained in our study is very high compared to that obtained by Liu et al. in 2008 [9] which is $23.4 \%$ on Passiflora edulis $f$. flavicarpa Degener. This indicates that these seeds studied constitute a good source of lipids.

Compared to other fruits, the seeds of Tetracarpidium conophorum are richer in oil than the fruit kernels of Spondias mombin L., studied by Ngakégni in 2012 [17] who obtained a value of $3 \%$ and the kernels of the fruit of the Cayor's apple tree (Neocarya macrophylla Sabine), studied by Balla and Baragé in 2008 [18] and which obtained a value of $0.4 \%$. This content is very high compared to $0.01 \%$, value obtained by Kabiru et al., [12] in 2015 on Borassus aethiopum

However, the value obtained in this study is slightly lower than those obtained by Chowdhury et al., [19] 2015 whose values oscillate between 49.20 and $50.76 \%$, working on five varieties of peanuts. They are also poor in oil compared to the nuts of Juglans regia (58.3- 65.2\%) studied by Tapia et al., in 2013 [20], but incorporates the values obtained by other authors (Mora-Escobedo et al., 2015 [21], by studying the physicochemical properties of eight varieties of peanuts cultivated in Mexico whose seed oil contents ranged from 37.9 to $56.3 \%$.

The seeds of the fruit of Tetracarpidium conophorum can be used in oil mills as a raw material in the production of vegetable oil for either food or cosmetic use.

\section{Protein content}

The seeds of the fruit of Tetracarpidium conophorum have an average protein content of $33.95 \%$. Some authors have obtained variable values for the same product, depending on the treatments applied: 11.78 value obtained by Suara et al., in 2016 [7]; $16.62 \%$ value obtained by Onawuni and Ayoola in 2013 [6]; 
$17.90 \%$ value obtained by Chikezie in 2017 [8]; 20.74\% value obtained by Nwaguipe et al., in 2012 [5]. All these values are low compared to that obtained in this study. This value of $33.95 \%$ is greater than $10.53 \%$, a value obtained by Liu et al. in 2008 [9], working on the seeds of Passiflora edulis f. flavicarpa Degener and also greater than $12.23 \%$, value obtained by Malacrida and Jorge in 2012 [10], working on the seeds of Passiflora edulis f. flavicarpa Degener. The seeds of Tetracarpidium conophorum are richer in protein than the seeds of Voandzou (Vigna subterranea L.) cultivated in Côte d'Ivoire, whose rates vary from 14.61 to $20.74 \%$ (Diallo Koffi et al., 2015) [4] and seeds of Parkia biglobosa (Jacq.), The rates of which vary from 24.33 to $33.70 \%$ (Koura et al., 2014) [22].

We can thus affirm that the seeds of Tetracarpidium conophorum are therefore proteinaceous.

\section{Ash content and major minerals}

The ash content of the seeds of Tetracarpidium conophorum studied is higher compared to the values found by Chikezie in 2017 (2.62\%) [8]; Nwaguikpe et al., in 2012 (3.18\%) [5] on the same product because it was around $9.14 \%$. This value of $9.14 \%$ is on the other hand close to the value found by other authors on the same product: $8.57 \%$ (Suara et al., in 2016) [7] and lower compared to 12.62 $\%$, value found by Onawuni and Ayoola in 2013 [6]. This value obtained in this study is very high compared to those obtained by Malacrida, and Jorge (2012) [10] and by Liv et al. in 2008) [9]), on the seeds of Passiflora edulis $f$. flavicarpa Degener, the values of which are respectively $1.27 \% ; 1.46 \%$ and $2.26 \%$. Ash is a good indicator of the concentration of mineral elements in a sample. Since the ash content is high, the seeds of the fruit of Tetracarpidium conophorum studied are therefore very rich in mineral elements.

Compared to other fruits, this value (9.14\%) is higher than $1.17 \%$, obtained on Borassus aethiopum by Kabiru et al. in 2015 [12] and those ranging from 1.38 to $1.48 \%$, obtained on peanut seeds by Ayoola and Adeyeye in 2010 [13] and Ayoola et al. in 2012 [14].

It is also higher than $4.08 \%$, a value obtained by certain authors (Bouazzaoui et al., 2016) [23], when working on melon seeds (Cucumis melo L. Inodorus) and those of other seeds of peanuts studied by Eshun et al. in 2013 [24], values ranging from 2.45 to $2.96 \%$. The "Manga" peanut has an ash content of $5.68 \%$ (Ossoko, 2017) [25], which is also low compared to that of the seeds studied here.

The result obtained in this study shows that there are still a lot of minerals to be determined in these ashes because the sum of the values found is less than $9.14 \%$. The high ash content justifies that the seeds of Tetracarpidium conophorum studied are very rich in mineral elements.

\section{Carbohydrate content}

This study shows a low carbohydrate content $(7.77 \%)$ of the seeds studied compared to the values found by other authors on the same product regardless of the treatments applied: $19.28 \%$ (Chikezie in 2017) [8 ]; $20.94 \%$ (Onawuni and Ayoola in 2013) [6]; 23.22\% (Nwaguikpe et al., in 2012) [5] and $51.18 \%$ (Suara et al., in 2016) [7] and also very low compared to the seeds of the fruit of Passiflora edulis f. flavicarpa Degener which is $48.94 \%$ (Ossoko et al., 2020) [26]. The seeds studied are also less rich in carbohydrates compared to the seeds of 
Passiflora edulis f. flavicarpa Degener studied by Liu et al., in 2008 [9] which obtained a value of $1.53 \%$. The value obtained in this study $(7.77 \%)$ is very low when compared to that obtained on the almonds of Borassus aethiopum (81\%) studied by Kabiru et al., in 2015 [12]. The carbohydrate content of certain varieties of peanuts: 17.41\% (Ayoola and Adeyeye 2010 [13]; Ayoola et al., 2012 [14]); $11.54-$ $19.65 \%$ (Eshun et al., 2013) [24] and $17.56 \%$ (Ossoko, 2017) [25] are high compared to the seeds of the fruit of Tetracarpidium conophorum, which is $7.77 \%$. The seeds studied here are therefore a poor source of carbohydrates.

\section{Dietary fiber rate}

The seeds of the fruit of Tetracarpidium conophorum which were the subject of our study are a very poor source of dietary fiber with a content of $0.15 \%$. This value is negligible compared to the values found by other authors on the same product regardless of the treatments applied: $1.24 \%$ (Chikezie, 2017) [8]; 1.56\% (Suara et al., 2016) [7]; $8.40 \%$ (Nwaguikpe et al., 2012) [5]; 14.92\% (Onawuni and Ayoola, 2013) [6]. This value is on the other hand very negligible compared to $17.48 \%$, value obtained by Liv et al., in 2008 [9] while working all on the seeds of Passiflora edulis $f$. flavicarpa Degener.

The seeds of the fruit of Tetracarpidium conophorum are therefore a very poor source of dietary fiber.

\section{Energy Value (VE)}

The energy value obtained on the seeds studied here is $591.23 \mathrm{Kcal} / \mathrm{100 \textrm {g }}$. This value is higher than that obtained on the seeds of Passiflora edulis f. flavicarpa Degener by Ossoko et al., in 2020 [26] which is $450.73 \mathrm{Kcal} / 100 \mathrm{~g}$. This value is also above those obtained by other authors on the same product, 398.04 Kcal / 100g, value obtained by Liu et al. in 2008 [9] also on Passiflora edulis $f$. flavicarpa Degener. This energy value is also higher than that obtained on the seeds of seven cultivars of voandzou [Vigna subterranea (I.) Verdc. Fabaceae] cultivated in Ivory Coast and studied by Diallo Koffi et al., 2015 [4] and which obtained values ranging from 370.02 to $388.8 \mathrm{Kcal} / 100 \mathrm{~g}$.

The seeds of the fruit of Tetracarpidium conophorum are therefore a very good source of energy.

\section{Conclusion and perspectives}

Tetracarpidium conophorum which has been the subject of our study is one of many plants that exist in our country and whose seeds have never been the subject of extensive scientific study. Almonds extracted from the seeds are high in fat, protein and low in carbohydrates. They are also good sources of minerals because their ash content is not negligible. These almonds are therefore a good source of nutrients and have a good energy value.

This work is far from over. As the ash content is high, it is important that a study be carried out to determine the rest of the mineral elements which so far are not known

This work should be completed by making an in-depth study of the lipid, carbohydrate and protein fractions of these almonds. Thus, these almonds would be valued in the production of the vegetable oil of Tetracarpidium conophorum.

Detailed analyzes on the various biochemical constituents of these almonds will be carried out in order to identify the maximum number of 
biomolecules such as glycolipids, antioxidants, isoprenides (terpenes, xanthophylls, carotenes, vitamin A, phylloquinones or vitamins $K$, tocopherols or vitamins $E, . .$.$) Likely to be of interest to$ the food and pharmaceutical industries.

\section{Bibliographical references}

[1]. Silou T., Biyoko S., Heron S., Tchapla A., Maloumbi M.G. (2004). Caractéristiques physico-chimiques et potentialités technologiques des amandes de Irvingia gabonensis. La Rivista italiana dell grasse (LXXXI): 49-56.

[2]. AOAC (2005). Official method of analysis of the Association of official Analytical Chemist, 5th ad. AOAC Press, Arlington, Virginia, USA.

[3]. Wolff J. P. (1968). Manuel d'analyse des corps gras; Azoulay éd., Paris (France), $519 \mathrm{p}$.

[4]. Diallo Koffi S., Koné Kisselmina Y., Soro D., Assidjo Nogbou E., Yao Kouassi B., Gnakri D. (2015). Caractérisation Biochimique et Fonctionnelle des Graines de Sept Cultivars de Voandzou (Vigna subterranea (L.) Verdc. Fabaceae) Cultivés en Côte d'Ivoire. European Scientific Journal. vol.11, No.27. 2-17 p.

[5]. Nwaoguikpe R N1, Ujowundu CO1, Wesley B (2012), Phytochemical and biochemical compositions of African Walnut (Tetracarpidium conophorum). Journal of Pharmaceutical and Biomedical Sciences@ (JPBMS), Vol. 20, Issue 20

[6] Onawumi, O.O.E., Faboya, O.O.P. \& Ayoola P.B., 2013. Chemical evaluation and nutritive values of African walnut leaf (Plukenetia conophora Mull.arg.), International Journal of Herbal Medicine 1(3), 122-126.

[7]. Suara, K.O., Azubuike, C.P., Okubanjo, O.O. \& Igwilo, C. (2016). Neutraceuticals and antibacterial properties of methanol extract of (Plukenetia conophora Müll.Arg.) family Euphorbiaceae leaves and physical properties of its cream formulations. Nigerian Journal of Pharmaceutical and Applied Science Research. 5(1): 91-98.

[8]. Chikezie,

Uchechukwu

Nkeirukayvonne (2017). Phyłochemical and Proximate Compositions of Tetracarpidium conophorum [African Walnut] Seeds. International Journal of Research Studies in Biosciences (IJRSB), vol. 5, no. 10, pp. 25-31.

[9]. Liu, S., Yang, F., Li, J., Zhang, C., Ji, H., and Hong, P. (2008). Physical and chemical analysis ofPassifloraseeds and seed oil from China.International Journal of Food Sciences and Nutrition, 59: 706715.

[10]. Malacrida R. C.and Jorge N., (2012). Yellow Passion Fruit Seed Oil (Passiflora edulis f.Flavicarpa): Physical and Chemical Characteristics. Brazilian Archives of Biology and Technology. Vol.55, n. 1: 127-134.

[11]. Jean WH, Yong, Liwa Ge, Yan Fei Ng and Swe Ngin Tan, 2009. The Chemical Composition and Biological of Coconut (Cocos nucifera) Water, Molecules 14: 5144-5164.

[12]. Kabiru Jega Umara, Bello Mani Abdullahib, Badaru Muhammadc, Sirajo Muhammadd, Lawal Gusau Hassane, Nasiru Alhaji Sanif. (2015). Nutritional and Antinutritional Profile of Borassus aethiopum Mart (African Palmyra Palm) Shoots. International Journal of Sciences: Basic and Applied Research (IJSBAR) ISSN 2307-4531 (Print \& Online), 1-11 p.

[13]. Ayoola P.B. and Adeyeye A. (2010). Effect of Heating on Chemical Composition and Physico-Chemical Properties of Arachis hypogaea 
(Groundnut) Seed Flour and Oil. Pakistan Journal of Nutrition 9 (8): 751-754

[14]. Ayoola P.B., Adeyeye A. and Onawumi O.O. (2012). Chemical evaluation of food value of groundnut (Arachis hypogaea) seeds. Am. J. Food. Nutr, 2(3): 55-57.

[15]. Brintha I., Mahendran T. and Seran TH. (2014). Nutritional Composition and Storage Stability of Groundnut (Arachis hypogaea L.) Seeds Cultivated with Organic Fertilizers. Tropical Agricultural Research and Extension 17(2).

[16]. Adegoke Bosede M., Shittu Suraj A., Raimi Monsurat M., Oyetade Olumide A., Oyekanmi Adeyinka M. (2014). Effect of Traditional Processing Methods on the Protein and Lipid Content of Arachis hypogaea (Groundnut). International Journal of Scientific and Research Publications, 4, Issue 5: 3 p.

[17]. Ngakegni-Limbili C.A. (2012). Etude de synergie des effets chimiques et biologiques des lipides de réserves et des huiles essentielles des fruits et graines saisonniers de la sous-région Afrique Centrale. Thèse, Université de Toulouse, 170p.

[18]. Balla A. et Barage M. (2008). Analyses physico-chimiques et caractérisation de la fraction lipidique des amandes du fruit du pommier de cayor (Neocarya macrophylla Sabine). Bulletin de la Recherche Agronomique du Benin: 6p.

[19]. Chowdhury F.N. Mst, Hossain D. Md, Hosen M. and Rahman S. Md. (2015). Comparative Study on Chemical Composition of Five Varieties of Groundnut (Arachis hypogaea). World Journal of Agricultural Sciences 11 (5): 247-254.

[20]. Tapia I. M., Sanchez-Morgado R. J., Garcia-Parra J., Ramirez R., Hernandez T.,
Gonzalez-Gomez D. (2013). Comparative study of the Nutritional and Bioctive compounds content of four Walnut (Juglans regia L.) cultivars. Journal of Composition and Analysis 31:232-237.

[21]. Mora-Escobedo R., Hermandez-Luna P., Joaquin-Torres I.C., Ortiz-Moreno A. and Robles-Ramirez M. Del C. (2015). Physicochemical properties and fatty acid profile of eight peanut varieties grown in Mexico. CYTA-Journal of Food, 13, 2: 300-304.

[22]. Koura k., Ouidoh G. I. P., Azokpota P., Ganglo C. J., et Hounhouigan J. D. (2014). Caractérisation physique et composition chimique des graines de Parkia biglobosa (Jaca.) R. Br. en usage au Nord-Benin. Journal of Applied Biosciences 75: 6239-6249.

[23]. Bouazzaoui N., Drici W., Bouazzaoui W., Lemerini W., Arrar Z., Bendiabdellah D. and Mulengi K. J. (2016). Fatty acids and mineral composition of melon (Cucumis melo L. Inodorus) seeds from West Algeria. Mediterranean Journal of Chemistry 5(1): 340-346.

[24]. Eshun G., Adu Amankwah E., and Barimah J. (2013). Nutrients content and lipid characterization of seed pastes of four selected peanut (Arachis hypogaea) varieties from Ghana. Glob. J. Food Sci. Technol. ISSN:1 (1): 108-114.

[25]. Ossoko J. P. L., (2017) : Valeur Nutritionnelle des Arachides (Arachis hypogaea L.) de "MANGA " : Etude de leurs Propriétés Lipidiques et Allergéniques. Thèse de Doctorat Unique. $142 \mathrm{p}$.

[26]. J.P.L. Ossoko, Y. Okandza, J. Enzonga Yoca, B.F. Mbété, M.G. Dzondo, M.D. Mvoula Tsieri. (2020) Biochemical Passion Fruit Seeds Characterization (Passiflora edulis F. Flavicarpa Denger) Cultivated in Republic of Congo. IOSR 
Journal of Biotechnology and www.iorsjournals.org, 6, 1: 48-54

Biochemistry (IOSR-JBB). 